\title{
Protecting the Warriors of COVID-19 Pandemic: Analysing the Mental Health of the Healthcare Workers
}

Faisal Azam ${ }^{1}$, Firdouse Rahman Khan², Sohar University, Oman

Email: ${ }^{1}$ Faisalazam753@gmail.com, ${ }^{2}$ firdouse4u@yahoo.co.uk

Citation: Azam, F., \& Khan, F.R (2021). Protecting the Warriors of COVID-19 Pandemic: Analysing the Mental Health of the Health Care Workers. International Journal of Research in Entrepreneurship \& Business Studies, 2(4), 37- 52. https://doi.org/10.47259/ijrebs.244

Received on $9^{\text {th }}$ Aug. 2021

Revised on $8^{\text {th }}$ Sep. 2021

Published on $10^{\text {th }}$ Oct. 2021

Copyright: (c) 2021 by the authors. Licensee Global Scientific Publications, Oman.

\section{Publishers Note:}

This work is licensed under a Creative Commons Attribution-ShareAlike 4.0 International License. This is an openaccess journal and the articles published in this journal are distributed under the terms of CC-BY-SA.

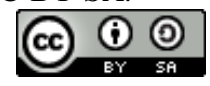

\section{Abstract}

Purpose: The research objective was to critically analyze the prevalence of any kind of mental health problem among healthcare workers (HCWs) and to investigate the factors affecting the mental health of HCWs and how they impact their mental health.

Design/methodology/approach: The data was collected using a structured questionnaire from the health care workers working in the leading hospitals from the Muscat region in Oman. The questionnaires were sent to more than 300 healthcare workers out of which only 202 of them filled and returned. The analysis was carried out using Smart Partial Least Squares (PLS).

Findings: The study revealed that during the pandemic, HCWs were having the typical symptoms of anxiety such as nervousness, difficulty in concentrating, restlessness, and too much fear for everything. They also had the symptoms of Depression such as frustration and no interest in doing things, feeling no energy to carry out their routines, and worrying about everything. They underwent the PTSD symptom of getting disturbing thoughts and memories. The results also revealed that the HCWs were constantly living under stress, frustration, and pressure which was directly affecting their routines and practices. Their frustration and stress were unnoticed and ignored as they continued treating the patients eventually.

Research limitations/implications: It is recommended that the concerned authorities should understand the psychological issues of the HCWs and provide appropriate facilities, training, and moral support. They can be motivated through lectures. Working hours and the number of patients can be reduced. Training for mental stress reliefs and more precautionary equipment should be provided to them to effectively fight against COVID19.

Social Implications: The mental health of healthcare professionals is imminent and cannot be ignored. The study helps the authorities in charge of HCWs to take appropriate and immediate action to observe and reduce anxiety and depression among those working in the frontline. Further, the timely logistic support, Pay raise, bonuses or rewards, expanded vacation time, and the full equipment for safety from COVID-19 could avoid such mental disturbances.

Originality / Value: There is no study on the mental health of HCWs in Oman. Due to lockdown and social boycotting, online surveys were the only available option left. Data were obtained from those HCWs who were computer literate and from a few health care institutes only. The study can be extended to include HCWs from other institutes as well.

Keywords: Mental Health, Healthcare Workers in Oman, Anxiety, PTSD, Depression, Psychological Status.

\section{Introduction}

Coronavirus disease 2019 (COVID-19) pandemic is the most unexpected unpleasant event that jeopardized the routine life world last year. All the health services and the health institutes were struggling day and night to combat the pandemic in saving the life of the people; especially the doctors and the paramedics were completely dedicating their services to fighting for the holy cause of saving humans (Alshekaili et al., 2020). 
They did not waste a single minute in dedicating their services and after all their efforts, there came a time when the results were seen by the entire world. The standard operating procedures (SOPs) were made and were peacefully followed widely. People got physically, socially, financially, and emotionally affected all over the world. COVID pandemic disturbed all the regular operations of the globe.

COVID-19 hit the world's health and the economy badly and the health care workers (HCWs) were working day and night restlessly for the betterment of the people. Either doctors or the paramedics, everyone was relentlessly involved in this job. During the entire health crisis, the health providers were the ones who were most affected in terms of mental health and psychological disturbances. They were exposed and in a vulnerable state to get infected easily. HCWs were the ones who openly come in contact with COVID patients and landed in trouble contracting and spreading the infection to their families (Naser, Dahmash, Alwafi, et al., 2020). HCWs fear that their families might be infected due to the pandemic (Lai et al., 2020). They were reluctant to work as they were experiencing stress, anxiety, and depression (Rajkumar, 2020). Indeed, they were the ones to directly deal with the pandemic without really knowing how possibly it could spread and cause while seeing people die now and then in front of their eyes. Though there was an exemption for the HCWs to travel during the night-time of lockdown, they were reluctant but kept on working without meeting their families. In this situation, they were working without break and rest but with fear of not messing up anything as it can cost lives. COVID-19 has taken away many loved ones from us during the outbreak. In all these situations, the most affected thing was their mental health (Serrano-Ripoll et al., 2020).

The disease not only affected physically but also made it even hard to survive with mental breakdowns. The pandemic has disturbed the health of HCWs psychologically, who stand in the frontline of the crisis. The following were certain key reasons for such mental disturbance:

1. Spreading of the news in the media that the disease was spreading too fast and furiously in uncontrollable ways leading to death and

2. The other was about the insecurity of the jobs (Shreffler et al., 2020).

Both this news imposed severe impacts on the minds of the doctors and the paramedics because the threat was directly upon their health and jobs. The pessimistic environment surrounded by these professionals is the major cause leading to their mental disturbance. Hence, it had become an utmost priority to monitor the mood, sleep, and other health issues of the HCWs to take measures for the same. Although precautionary measures in the form of providing masks, gloves, PPEs, and sanitizers are given the unseen mental issues are not at all noticed and rather ignored by the senior officials. There is indeed the fear of the authenticity of the Personal Protective Equipment (PPEs) used in the pandemic environment. There was no guarantee that the PPEs were sufficient enough to provide proper and complete protection to the HCWs. Even after so much concern and precautions, most of them got the disease and many died due to infection. All of this had a direct impact on them, especially made them mentally disturbed.

Like all the other citizens of the state, these HCWs also have to maintain the social distancing and follow all the SOPs given by the state but on the other hand, their stress and anxiety level is far more than that of the local citizens because they are still in contact with the patients and many of them who are declared corona positive (Badahdah et al., 2020). Despite the resilience of these health workers, the effects of the damage caused by the coronavirus were still eminent. The vast and frantic extent of the disease caused many families to lose lives, financial losses and faced psychological issues. Most of the people who got themselves isolated to remain safe from the virus also developed similar mental issues and on the other hand, the HCWs were regularly dealing with ill patients and the fear of taking the disease at home was at its peak. They underwent a different kind of mental trauma that included all sorts of stress-related issues. The continuous fear of death and meeting ill family members is a critical factor that made a person mentally sick.

During the pandemic, the regular functioning of many companies and entities got fiercely affected. It badly hit the economies of numerous states (Roy et al., 2021). COVID-19 pandemic has caused great financial and psychological disorders. People lost their jobs, people started living in complete isolation. This caused depression, insomnia, fatigue, suicidal thoughts, constant fear, and many more mental issues. A year delay in producing a vaccine for the Coronavirus was also a reason that everyone became desperate. Everyone was equally affected in other countries as well (De Kock et al., 2021). Among all the professionals, the medical profession was under the greatest threat as it was badly hit by COVID-19 (Di Tella et al., 2020). The medical professionals did not have the fear of losing their jobs rather they were more fearful about losing their lives and the health of their loved ones as they were directly in contact with the patients of Corona. 
Mental health among HCWs has become a major concern since the COVID-19 outbreak (Lam et al., 2020). Nobody is aware of the time limit of the disease and nobody was aware when the vaccine would arrive that would eventually eradicate the disease from the world. Till then, dealing with the corona-positive patients constantly and living in fear is the only option. Living and working with full precautions make life more difficult as wearing PPEs constantly was also a difficult task.

Special schemes are offered to upcoming entrepreneurs by the Riyada Public Authority for SMEs Growth. Further, SANAD and Al Raffd Funds have also been specifically established for Omani youth. The SANAD program is targeting the age group 18-40 years. This group range fresh graduates and job seekers who are all interested in starting new businesses or expanding existing businesses (UNESCO-UNEVOC International Centre, 2012). Students are given special training programs in the field of entrepreneurship as a part of their curriculum. However, the impact of these shifts in student intentions on entrepreneurship is not known as it was never evaluated.

Though entrepreneurial analysis has spread considerably, there is a long list of factors that affect entrepreneurship. There is no full consensus that the need for performance and the locus of control will justify the intent of people to start businesses. Habit is one of the motivating forces for intentions and attitudes are the specific behavior people respond to in situations, and challenges. This is despite the gender differences arising among the motivating the moderating influences towards entrepreneurship, self-efficiency of entrepreneurs, and the desire for success (Vodă \& Florea, 2019). Independence and taking chances do not impact the entrepreneurial purpose of students coordinating their ventures directly.

\section{Problem statement}

People got physically, socially, financially, and emotionally affected all over the world. Indeed, the viral outbreak of the virus led the World Health Organization (WHO) to declare the public health emergency of international concerns over COIVD-pandemic (Serrano-Ripoll et al., 2020). As the pandemic hit the masses, many got affected but the front-line HCWs were undoubtedly the first ones who were affected by the pandemic. They were the ones who are affected by COVID more than the non-frontline workers. The physical and emotional effects of the COVID are still visibly observed in many health institutions in the entire world. The real issue which was left unnoticed and unknowingly ignored was the mental condition of the health care workers.

The helplessness of HCWs who got directly affected by the disease was of quite a major concern to the administrators and the government because it eventually affected the overall system of health. The doubtful behavior of the health workers about the eradication of the disease is still a question and the late formation of the antivirus led to many other societal problems as well. The tiredness, sleep deprivation, fear, anxiety, tension, trauma, disturbance, and lastly the suicidal cases were at large due to the spread of the disease and the damage it caused in the society. Many of these mentioned disorders were also reported from the HCWs sides as well. The medicos were the most neglected ones to get hit by the wave of epidemic and its harmful effects.

The adverse effect on mental health care due to the COVID pandemic was not studied properly and hence needs utmost attention and requires a thorough study on the psychological status of such mentally disturbed health service providers - the lifesaving soldiers.

\section{Research Questions}

1. What is the psychological status of the healthcare workers (HCWs)?

2. What were the factors affecting the mental health of the healthcare workers during the pandemic period?

\section{Research Objectives}

1. To critically investigate the prevailing psychological status of the healthcare workers (HCWs).

2. To analyze the factors affecting the mental health of the healthcare workers (HCWs) and the impact on their mental health.

\section{Review of Literature \\ Mental Health}

COVID-19 cases were reported to be asymptomatic (Day, 2020). The improper protective measure given to the health care workers might hike psychological distress and affect their mental well-being. Mental illhealth drastically affects Healthcare Professionals' (HCPs) performance and psychological well-being is essential for an individual to perform well (Schafheutle et al., 2011; Wallace et al., 2009). Li et al. (2003) 
and Lai et al. (2020) claimed that the female HCPs were the ones who were easily prone to developing depression and anxiety. The impact of the pandemic on mental health was observed to be very high among female healthcare professionals (Naser, Dahmash, Al-Rousan, et al., 2020). Khanal et al. (2020) using the Hospital Anxiety and Depression Scale (HADS) identified that anxiety, depression, and insomnia symptoms were found to prevail among the health workers involved in the early phase of the pandemic in Nepal. Özdin and Bayrak Özdin (2020) using HADS found that the females were the most affected due to anxiety disorders during COVID-19 in Turkey. Lai et al. (2020) confirmed that the majority were found to suffer from depression followed by anxiety and insomnia. Liu et al. (2020) identified the factors associated with depression, anxiety, and PTSD were solitary, fear, and low pain-bearing capacity. Johnson et al. (2020) reported that the health workers and public service providers are experiencing high levels of PTSD symptoms, anxiety, and depression during the COVID-19 pandemic. In the initial phase of COVID-19, medicos were reported to have affected mostly by anxiety, followed by PTSD and depression. The mental trauma and anxiety due to the pandemic occurring not only to the patients but also to the HCPs who are involved in treating COVID patients (Rajkumar, 2020; Tandon, 2020). Li et al. (2020) stated that utmost attention should be paid to the medical staff, especially front-line workers as their psychological problems during COVID-19 are alarming. HCWs were experiencing potentially morally injurious events that may violate their moral code or values (Borges et al., 2020). A considerable proportion of HCWs experienced sleep disturbances during this outbreak, stressing the need to establish ways to mitigate mental health risks (Pappa et al., 2020).

\section{Anxiety}

Peteet (2020) reported that there were growing concerns of anxiety due to COVID-19 and the need for psychological treatment. Mazza et al. (2020) reported that PTSD, Depression, Anxiety followed by Obsessive-Compulsive symptoms were associated with the COVID-19. Despite Healthcare workers' (HCWs) resilience, many of them have experienced psychological trauma that exceeded their capacity to manage during the COVID outbreak (Greenberg et al., 2020; Matheson et al., 2016). Healthcare workers especially nurses working in the Ministry of Health reported that they were not able to maintain work-life balance due to the mounting pressure in their work and hence wanted to get transferred to the administrative side (Al-Balushi, 2016) and thus the patients prefer in approach private hospitals rather than public hospitals (Al-Balushi \& Khan, 2017).

Choi et al. (2020) confirmed that the psychological status of the people in Hong Kong during the COVID-19 pandemic, got affected for various reasons and the majority of the people were affected by the depression and anxiety of disorders. Compared to the general population, front-line HCWs had higher odds of endorsing total trauma-related symptoms like Anxiety, Depression, and insomnia (Rossi et al., 2020). Hyland et al. (2020) estimated the prevalence rate of generalized anxiety disorders and depression due to COVID-19 in Ireland found that anxiety was highest among the society. Economic effects of COVID-19 result in anxiety disorder mostly among adults than the elderly (Mann et al., 2020). Sher (2020) claimed that during COVID19 , sleep disturbances were affected with anxiety, depression leading to suicidal attempts.

\section{Depression}

Depression is thought of as being unable to do or control the condition and the depression scores of females were found to be higher during the pandemic as they had anxiousness experienced depression (Ustun, 2021). Medical health workers went through every kind of mental breakdown with them facing every single-phase depression, breakouts, panic, etc. (Shreffler et al., 2020). The prevalence of HCPs with high-level depressive symptoms was found in India during the pandemic (Wilson et al., 2020). The depression symptoms were reported higher in the US during the COVID-19 pandemic compared with before the COVID-19 situation and it might lead to an increase in mental illness among the at-risk populations (Ettman et al., 2020). Females, singles, and frontline workers were associated with higher scores of symptoms of depression, anxiety, and stress (Elbay et al., 2020). Lam et al. (2020) identified the factors causing depression among HCWs as close contact, inadequate provision of PPEs, and insufficient infection control training.

\section{PTSD}

Carmassi et al. (2020) claimed that a high percentage of Health care workers HCWs developed Post-traumatic Stress Disorder (PTSD) during COVID-19. HCWs were the moderately affected ones due to COVID-19, especially the females were the ones who had more impact (Blekas et al., 2020). Psychological consequences of the COVID-19 were observed to result in serious post-traumatic stress disorder (PTSD) and depression (Tang et al., 2020). Johnson et al. (2020) reported that the health workers who were directly involved in treating COVID-19 patients got severe PTSD symptoms and depression compared to others. Conversano et 
al. (2020) claimed that the occurrence of PTSD appeared to be common among frontline HCWs during the COVID pandemic, and emotional support is the only means to reduce such psychological effects of the pandemic.

From the review of literature, three independent variables viz. anxiety, depression, and PTSD have been identified and their impact upon the dependent variable mental healthcare of the health care workers due to the effect of COVID-19 was dealt with. Lockdown and fight conditions being created due to the unknown nature of the disease contributed to the cause.

\section{Research Methodology}

According to the respondents, the health issues such as Anxiety, Depression, Post-Traumatic Stress Disorder (PTSD) - Change in psychological status were found among the health workers as they showed vital signs of these mental issues during the pandemic period. The doctors and the paramedical staff of the hospitals who got directly involved with the Corona patients and faced all the emotional instability at the time were considered for the study (Badahdah et al., 2020).

The data was collected using a structured questionnaire, from the health care workers working in the leading hospitals - 10 health care institutes including polyclinics, public hospitals, and tertiary and secondary care hospitals from the Muscat region in Oman. The health care centers not just include the hospitals, but our study undergoes as well.

The questionnaires were sent to the doctors and paramedical staff online and responses were obtained. The respondents were those who had direct contact with the corona-infected patients. The confidentiality of the data was fully considered and secrecy of the information was maintained. The structured questionnaire contained 37 statements. The questionnaires were sent to more than 300 healthcare workers out of which only 202 of them filled and returned. The analysis was carried out using the filled questionnaires.

\section{Findings}

Table 1

Demographics Details

\begin{tabular}{|c|l|c|c|}
\hline Characteristics & & Frequency & \% \\
\hline \multirow{3}{*}{ Gender } & Male & 65 & 32.2 \\
\cline { 2 - 4 } & Female & 137 & 67.8 \\
\hline \multirow{5}{*}{ Nationality } & Omani & 144 & 71.3 \\
\cline { 2 - 4 } & Non-Omani & 58 & 28.7 \\
\hline \multirow{4}{*}{ Marital Status } & 19 years or less & 4 & 2.0 \\
\cline { 2 - 4 } & 20 less than 30 & 126 & 62.4 \\
\cline { 2 - 4 } & 30 less than 40 & 55 & 27.2 \\
\cline { 2 - 4 } & 40 less than 50 & 16 & 7.9 \\
\cline { 2 - 4 } & 50 less than 60 & 1 & 0.5 \\
\cline { 2 - 4 } & Uarried & 138 & 68.3 \\
\hline \multirow{5}{*}{ Educationation level } & Enmloyed & 64 & 31.7 \\
\cline { 2 - 4 } & Unemployed & 139 & 68.8 \\
\cline { 2 - 4 } & Look for job & 32 & 15.8 \\
\hline & University/degree & 132 & 15.3 \\
\cline { 2 - 4 } & Uneducated & 7 & 65.3 \\
\cline { 2 - 4 } & Secondary school & 9 & 3.5 \\
\cline { 2 - 4 } & Diploma & 39 & 19.3 \\
\cline { 2 - 4 } & Postgraduate & 15 & 7.4 \\
\hline \multirow{5}{*}{ Residence } & Muscat & 75 & 37.1 \\
\cline { 2 - 4 } & Sohar & 58 & 28.7 \\
\cline { 2 - 4 } & Seeb & 4 & 2.0 \\
\cline { 2 - 4 } & Salalah & 1 & 0.5 \\
\cline { 2 - 4 } & Bowsher & 4 & 2.0 \\
\cline { 2 - 4 } & Liwa & 25 & 12.4 \\
\cline { 2 - 4 } & As Suwayq & 9 & 4.5 \\
\hline
\end{tabular}




\begin{tabular}{|l|l|l|l|}
\hline & Ibri & 5 & 2.5 \\
\cline { 2 - 4 } & Saham & 9 & 4.5 \\
\cline { 2 - 4 } & Rustaq & 5 & 2.5 \\
\cline { 2 - 4 } & Buraimi & 3 & 1.5 \\
\cline { 2 - 4 } & Nizwa & 3 & 1.5 \\
\cline { 2 - 4 } & Sur & 1 & 0.5 \\
\hline
\end{tabular}

Source: Questionnaire

Table 2

Details of Latent variables and Apparent variables

\begin{tabular}{|c|c|c|}
\hline $\begin{array}{c}\text { Factors (Latent } \\
\text { variables) }\end{array}$ & & $\begin{array}{c}\text { Sub-factors } \\
\text { (Apparent variables) }\end{array}$ \\
\hline \multirow{7}{*}{ Anxiety } & a1 & Feeling Nervous and anxious or the edge \\
\hline & $\mathrm{a} 2$ & Starting to worry too much about various things \\
\hline & a3 & Not being able to stop or control worrying \\
\hline & $\mathrm{a} 4$ & Being so restless that it is hard to sit still \\
\hline & a5 & Becoming easily annoyed or irritable \\
\hline & a6 & Difficulty in concentrating \\
\hline & a7 & Feeling afraid as if something awful might happen \\
\hline \multirow{9}{*}{ Depression } & $\mathrm{d} 1$ & Nowadays have little or no interest in doing things \\
\hline & $\mathrm{d} 2$ & Feeling down or hopeless \\
\hline & $\mathrm{d} 3$ & Feeling tired or having little energy \\
\hline & $\mathrm{d} 4$ & Poor appetite or over-eating \\
\hline & $\mathrm{d} 5$ & Trouble concentrating on things \\
\hline & d6 & Feeling reckless or thoughts of hurting yourself \\
\hline & $\mathrm{d} 7$ & Inability to feel positive emotions \\
\hline & $\mathrm{d} 8$ & Feel like been trapped or caught \\
\hline & d9 & Worry too much about things \\
\hline \multirow{9}{*}{$\begin{array}{l}\text { Effects on } \\
\text { Mental Health } \\
\text { due to COVID- } \\
19\end{array}$} & $\mathrm{~m} 1$ & Able to concentrate on work \\
\hline & $\mathrm{m} 2$ & Could not sleep because of worries \\
\hline & $\mathrm{m} 3$ & Able to make decisions \\
\hline & $\mathrm{m} 4$ & Felt constantly under strain \\
\hline & $\mathrm{m} 5$ & Felt that could not overcome my difficulties \\
\hline & $\mathrm{m} 6$ & Unable to enjoy normal day-to-day routine activities \\
\hline & $\mathrm{m} 7$ & Feeling unhappy and depressed \\
\hline & $\mathrm{m} 8$ & feeling like losing self-confidence \\
\hline & $\mathrm{m} 9$ & Happy with the work assigned to me \\
\hline \multirow{5}{*}{ PTSD } & p1 & Had repeated, disturbing memories, thought \\
\hline & $\mathrm{p} 2$ & Experiencing strong fear that causes panic \\
\hline & p3 & Been constantly on guard, watchful \\
\hline & $\mathrm{p} 4$ & Felt numb or detached from people \\
\hline & p5 & Felt guilty \\
\hline
\end{tabular}

The latent variables \& apparent variables were tested together using the measurement model. 
Figure 1

Conceptual Model

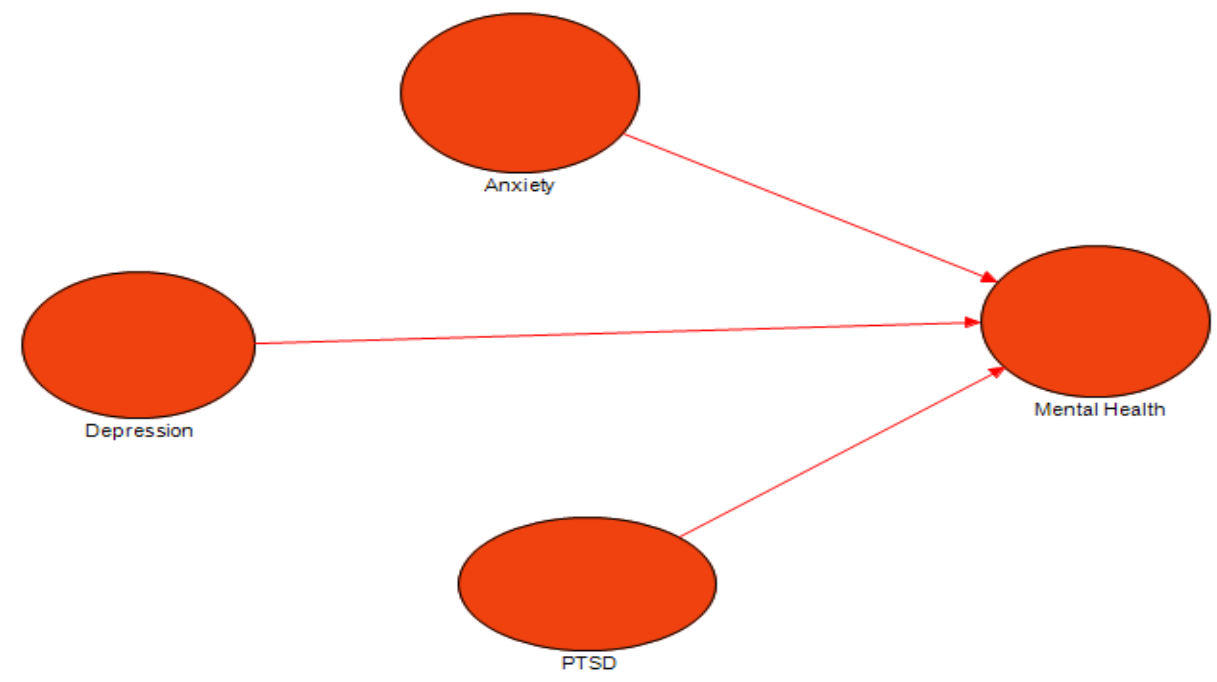

Tenenhaus et al. (2005) pointed out that the quality of the prescribed model can be ensured in three steps

i) Determining the measurement model

ii) Defining the structural model, and

iii) Deriving the structural regression equation.

\section{Measurement Model}

The conceptual model shows that there is a relationship between Depression, Anxiety, PTSD, and the Mental Health of Healthcare Workers. To confirm the reliability, discriminant and convergence are confirmed (Henderson et al., 2012). The values of the factor loadings are shown in Figure 2.

\section{Figure 2}

Initial Path Model

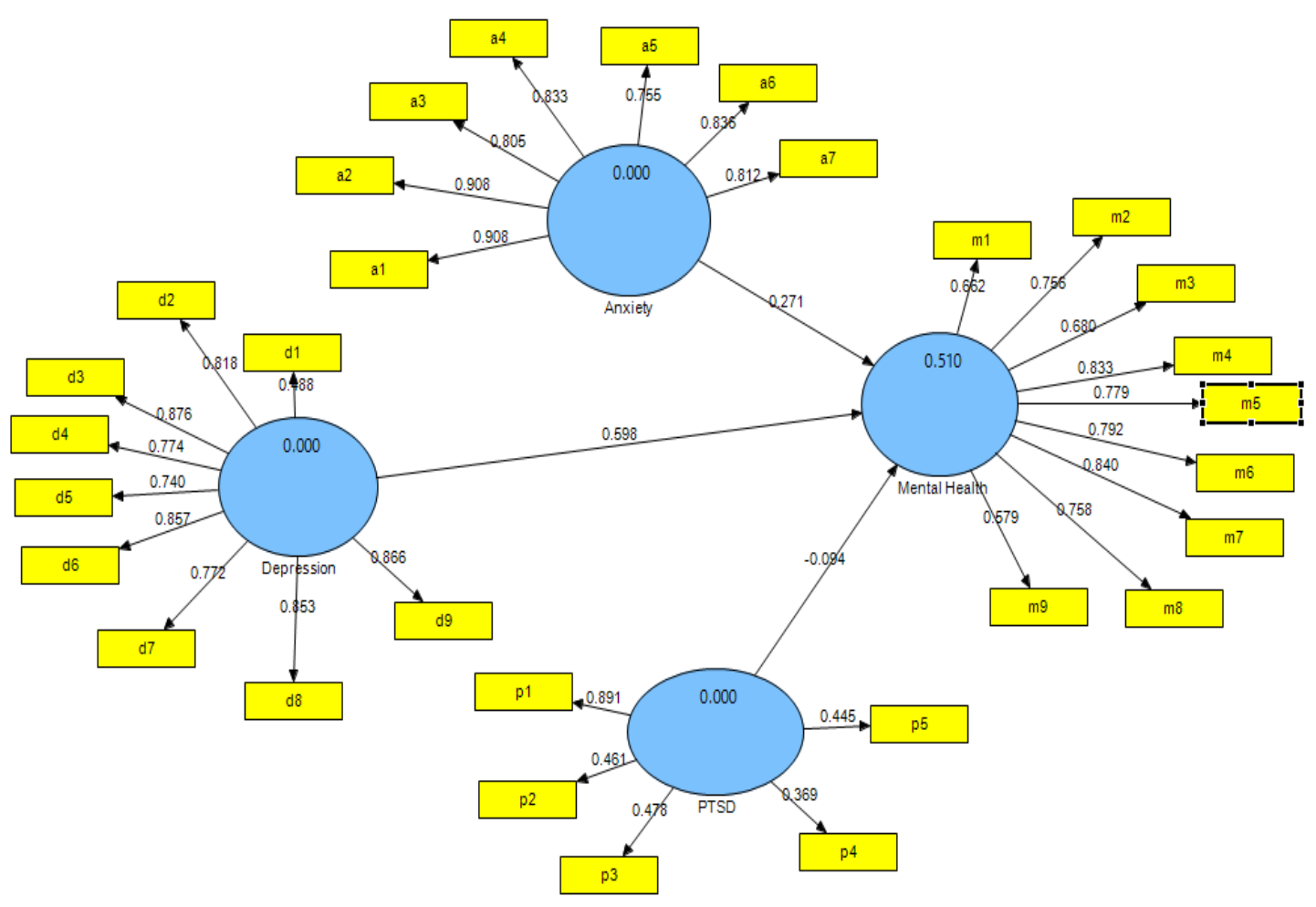


The measurement model's reliability is confirmed through the factor loadings (FL). If FL > 0.45 is preferable (Comrey \& Lee, 2013). The sub-factors > 0.70 only were taken into consideration (Hulland, 1999) and the others were eliminated and the final path model is obtained.

Figure 3

Final Path Model

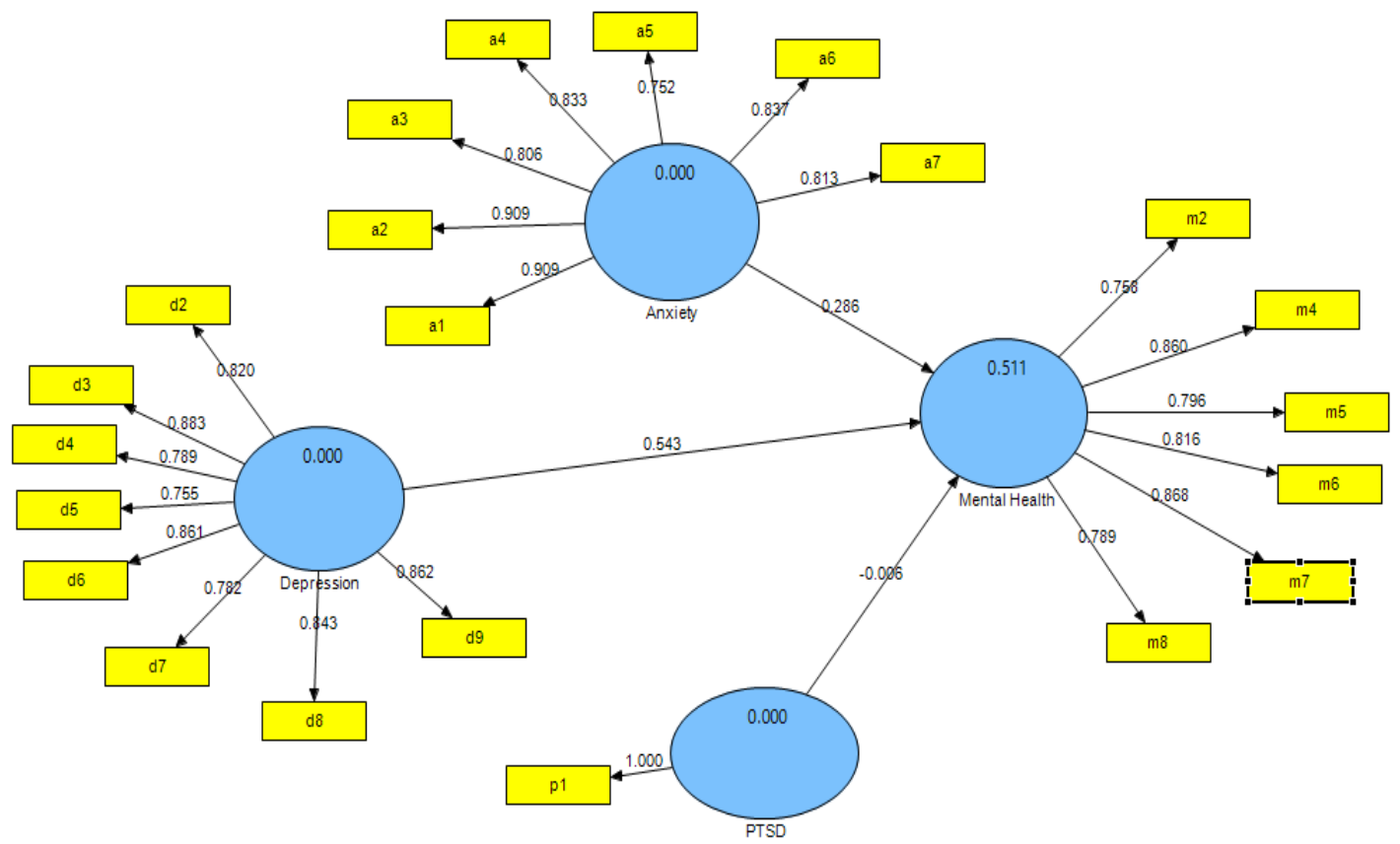

\section{Reliability}

Reliability and inner consistency can be decided more on composite reliability (CR) than Cronbach Alpha (CA) (Hair et al., 2012). Composite reliability $>0.7$ and Cronbachs alpha $>0.6$ would be preferable (Gefen et al., 2000; Hair et al., 1998). FL, CR, and CA values are presented in Table 3. CA scores $>0.898$ and CR scores $>0.922$ which confirms that the model is suitable.

Table 3

Factor loading for indicators of latent constructs

\begin{tabular}{|c|c|c|c|c|c|}
\hline & Factors \& Sub-factors & FL & $\mathbf{C A}$ & $\mathbf{C R}$ & AVE \\
\hline $\mathbf{a}$ & Anxiety & & 0.92876 & 0.94288 & 0.70303 \\
\hline a1 & $\begin{array}{l}\text { Feeling Nervous and anxious or } \\
\text { the edge }\end{array}$ & 0.90870 & & & \\
\hline a2 & Started to loose concentration & 0.90870 & & & \\
\hline a3 & $\begin{array}{l}\text { Not being able to stop or control } \\
\text { worrying }\end{array}$ & 0.80569 & & & \\
\hline $\mathrm{a} 4$ & $\begin{array}{l}\text { Being so restless that it is hard to } \\
\text { sit still }\end{array}$ & 0.83252 & & & \\
\hline a5 & $\begin{array}{l}\text { Becoming easily annoyed or } \\
\text { irritable }\end{array}$ & 0.75223 & & & \\
\hline a6 & Difficulty in concentrating & 0.83696 & & & \\
\hline a7 & $\begin{array}{l}\text { Feeling afraid as if something } \\
\text { awful might happen }\end{array}$ & 0.81312 & & & \\
\hline d & Depression & & 0.93278 & 0.94466 & 0.68147 \\
\hline $\mathrm{d} 2$ & Feeling down or hopeless & 0.81994 & & & \\
\hline d3 & $\begin{array}{l}\text { Feeling tired or having little } \\
\text { energy }\end{array}$ & 0.88315 & & & \\
\hline $\mathrm{d} 4$ & Poor appetite or over-eating & 0.78887 & & & \\
\hline $\mathrm{d} 5$ & Trouble concentrating on things & 0.75499 & & & \\
\hline
\end{tabular}




\begin{tabular}{|c|c|c|c|c|c|}
\hline d6 & $\begin{array}{l}\text { Feeling reckless or thoughts of } \\
\text { hurting self }\end{array}$ & 0.86123 & & & \\
\hline $\mathrm{d} 7$ & $\begin{array}{l}\text { Inability to feel positive } \\
\text { emotions }\end{array}$ & 0.78156 & & & \\
\hline $\mathrm{d} 8$ & Feel like been trapped or caught & 0.84314 & & & \\
\hline d9 & $\begin{array}{l}\text { Worry too much about } \\
\text { everything }\end{array}$ & 0.86240 & & & \\
\hline $\mathbf{m}$ & Mental Health & & 0.89877 & 0.92246 & 0.66526 \\
\hline $\begin{array}{ll}\mathrm{m} \\
2\end{array}$ & $\begin{array}{l}\text { Could not sleep because of } \\
\text { worries }\end{array}$ & 0.75787 & & & \\
\hline $\begin{array}{l}\mathrm{m} \\
4\end{array}$ & Felt constantly under strain & 0.86022 & & & \\
\hline $\begin{array}{ll}\mathrm{m} \\
5\end{array}$ & $\begin{array}{l}\text { Felt that could not overcome my } \\
\text { difficulties }\end{array}$ & 0.79648 & & & \\
\hline $\begin{array}{ll}\mathrm{m} \\
6\end{array}$ & $\begin{array}{l}\text { Unable to enjoy normal day-to- } \\
\text { day routine activities }\end{array}$ & 0.81634 & & & \\
\hline $\begin{array}{l}\mathrm{m} \\
7\end{array}$ & Feeling unhappy and depressed & 0.86807 & & & \\
\hline $\begin{array}{l}\mathrm{m} \\
8\end{array}$ & $\begin{array}{l}\text { feeling like losing self- } \\
\text { confidence }\end{array}$ & 0.78924 & & & \\
\hline $\mathbf{p}$ & PTSD & & 1 & 1 & 1 \\
\hline $\mathrm{p} 1$ & $\begin{array}{l}\text { Had repeated disturbing } \\
\text { memories and thoughts }\end{array}$ & 1 & & & \\
\hline
\end{tabular}

\section{Convergent Validity (CV)}

To validate convergent validity

i) the values of the factor loadings $\geq 0.70$ (Hulland, 1999) and

ii) AVEs should be $>0.50$ (Bagozzi \& Yi, 1988); 0.4 is tolerable if composite reliability (CR) $>0.6$ (Fornell \& Larcker, 1981; Huang et al., 2013).

AVE ranges from 0.665 to 0.703 (Table 3), and hence $\mathrm{CV}$ is acceptable.

\section{Discriminant Validity (DV)}

Discriminant validity in PLS shows that the construct has a robust relationship to the other constructs. Correlations between constructs (Table 4) confirm that DV is satisfactory.

Table 4

Discriminant Validity Results

\begin{tabular}{|l|c|c|c|c|}
\hline & Anxiety & Depression & Mental Health & PTSD \\
\hline Anxiety & 1 & & & \\
\hline Depression & 0.45202 & 1 & & \\
\hline Mental Health & 0.52877 & 0.66781 & 1 & \\
\hline PTSD & 0.35721 & 0.65591 & 0.45171 & 1 \\
\hline
\end{tabular}

\section{Structural Model}

Path coefficient values indicate the relationship between $\mathrm{R}^{2}$ and the dependent and independent variables. The bootstrapping test values appear in Table 5 . 
Table 5

Path coefficients along with their Bootstrap values and T-values

\begin{tabular}{|l|c|c|c|c|c|c|c|}
\hline \multicolumn{1}{|c|}{ Factors } & Sample & Mean & $\begin{array}{c}\text { Std. } \\
\text { Deviation }\end{array}$ & $\begin{array}{c}\text { Std. } \\
\text { Error }\end{array}$ & T Statistics & Supported & Sig. \\
\hline $\begin{array}{l}\text { Anxiety -> } \\
\text { Mental } \\
\text { Health }\end{array}$ & 0.28567 & 0.27425 & 0.09698 & 0.09698 & 2.94581 & Yes & $\begin{array}{c}\mathrm{p}<0.05 \\
1.96\end{array}$ \\
\hline $\begin{array}{l}\text { Depression -> } \\
\text { Mental } \\
\text { Health }\end{array}$ & 0.54291 & 0.55615 & 0.07997 & 0.07997 & 6.78916 & Yes & -- \\
\hline $\begin{array}{l}\text { PTSD -> } \\
\text { Mental } \\
\text { Health }\end{array}$ & -0.00644 & -0.00546 & 0.06110 & 0.06110 & 0.10540 & No & $\begin{array}{c}\mathrm{p}<0.05 \\
1.96\end{array}$ \\
\hline
\end{tabular}

The association between Anxiety and Mental Health was confirmed as $\beta=0.28567$ and $t=2.4581(>1.96)$ at $\mathrm{p}_{.05}$. i.e. Mental Health was positively influenced by Anxiety.

The association between Depression and Mental Health was confirmed as $\beta=0.54291$ and $\mathrm{t}=6.78916$ (>1.96) at p.05. i.e. Mental Health was positively influenced by Depression.

The association between PTSD and Mental Health was insignificant as $\beta=-0.00644$ and $t=0.10540(<1.96)$ at $\mathrm{p}_{.05}$. i.e. PTSD factors did not influence Mental Health.

In other words, Mental Health was positively influenced by Anxiety and Depression, but not by PTSD.

Figure 4

Bootstrapping Diagram

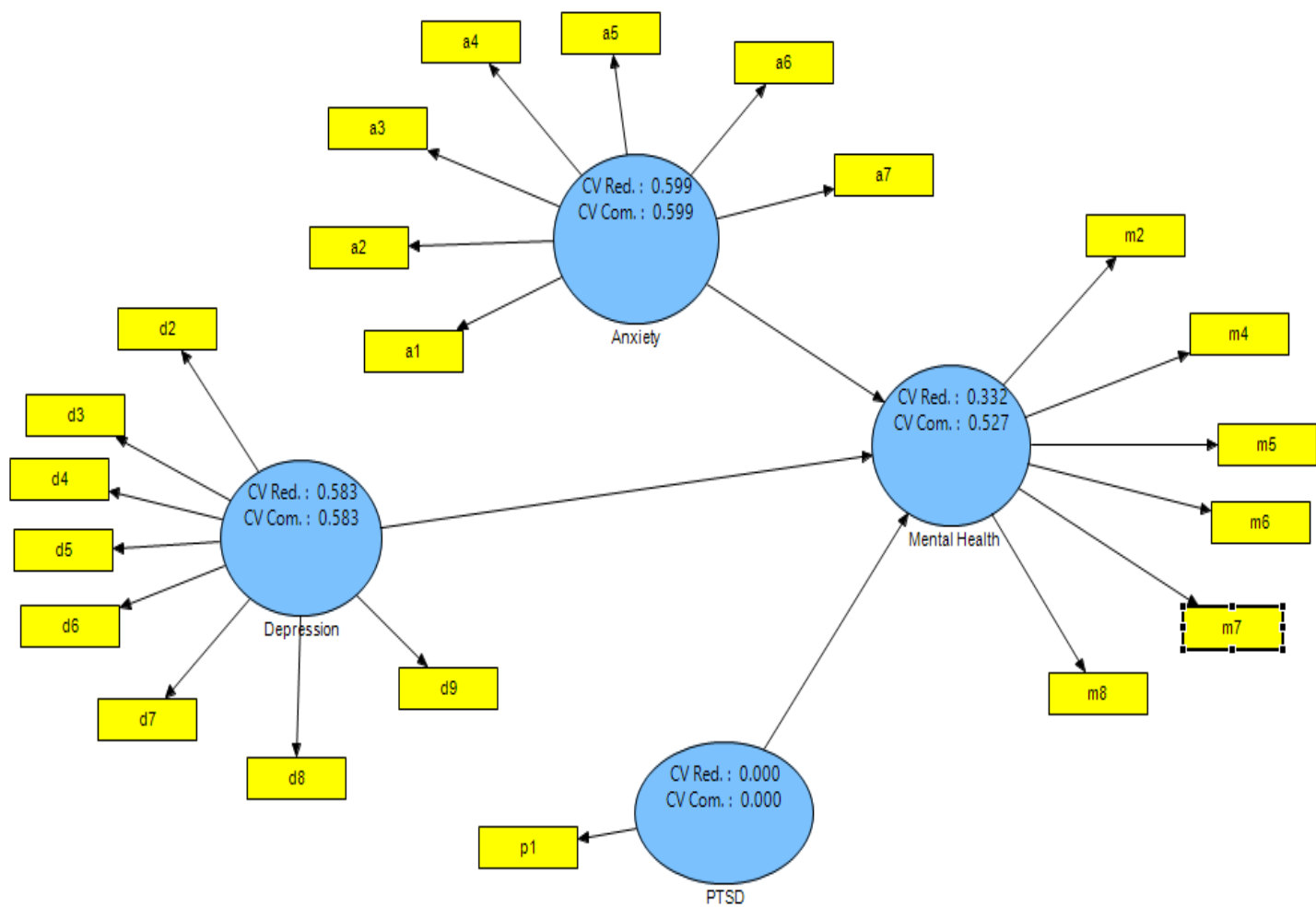




\section{Assessment of Fit}

Goodness-of-fit (GOF) denotes the overall model fit.

It is given by the formula

GOF $=$ SQRT (average $\mathrm{R}^{2} \mathrm{x}$ average communality)

$=\operatorname{SQRT}(0.510706 \times 0.76244)=0.624005$

Table 6

Model Evaluation Results

\begin{tabular}{|c|c|c|c|c|c|}
\hline Factors & $\mathbf{R}^{2}$ & Communality & $\mathbf{H}^{2}$ & Redundancy & $\mathbf{F}^{2}$ \\
\hline Anxiety & & 0.70303 & 0.59936 & & 0.59936 \\
\hline Depression & & 0.68147 & 0.58288 & & 0.58288 \\
\hline Mental Health & 0.510706 & 0.66526 & 0.52661 & 0.14527 & 0.52661 \\
\hline PTSD & & 1 & & & \\
\hline & 0.510706 & 0.76244 & & & \\
\hline
\end{tabular}

In PLS, The structural model \& hypothesis is tested using the path coefficients $(\beta)$ and $\mathrm{R}^{2}$ for dependent latent variables \& Average Variance Extracted (AVE) (Cohen et al., 2014; Fornell \& Larcker, 1981).

$\mathrm{R}^{2}$ shows the construct's percentage variation illuminated by the model (Wixom \& Watson, 2001). $\mathrm{R}^{2}>0$ $\Rightarrow$ model has predictive significance

$\mathrm{R}^{2}<0 \Rightarrow$ model lacks (Figure 5).

Figure 5

Blind Folding Path Diagram

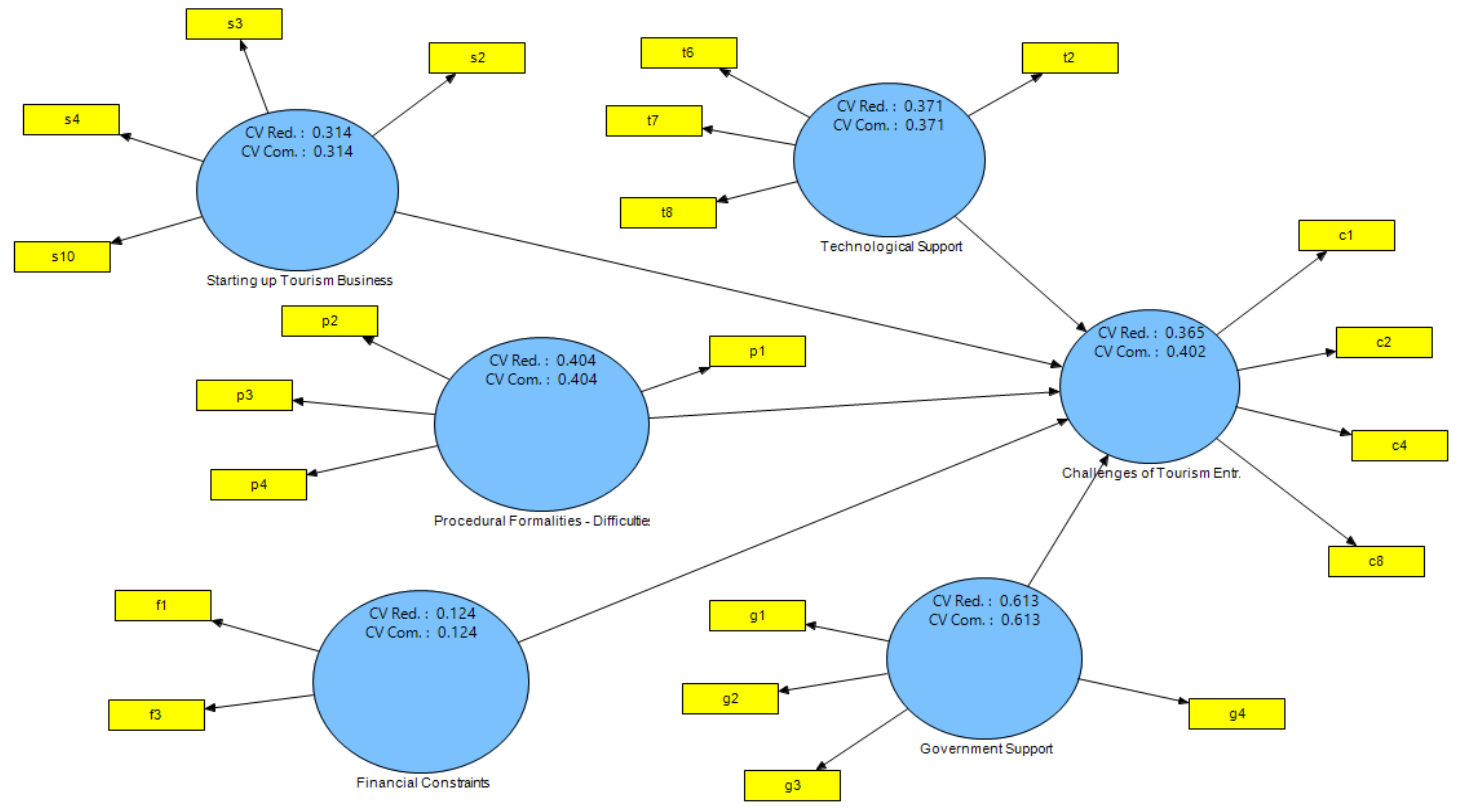

\section{Results}

Anxiety

Most of the respondents reported that 'They were feeling nervous and anxious' and 'they started to lose concentration as the major anxiety issues faced by them, followed by 'Being so restless that is hard to sit still' 'Feeling afraid as if something awful might happen'. 
Depression

Most of the respondents agreed that 'They felt like having little or no interest in doing things' was the main Depression issue followed by 'They were feeling tired or felt like having little energy' and 'worrying too much about everything'.

\section{PTSD}

Most of the respondents reported that 'They had repeated disturbing memories and thoughts' was the main PTSD issue.

\section{Mental Health}

As far as the mental health of the HCWs is concerned, most of the respondents reported that 'They were feeling unhappy and depressed' followed by 'felt constantly under strain' and 'Unable to enjoy normal dayto-day routine activities'.

From the findings, it was confirmed that Mental Health was positively influenced by Anxiety and Depression but not by PTSD. The result of impact is similar to that of Ornell et al. (2020) in which they claimed anxiety, stress, and depression have been highly experienced by the HCWs due to the COVID-19 pandemic.

$68.3 \%$ of the respondents who were married people claimed that they were not able to pay attention to their families due to the mental disturbances during the pandemic. They reported being mentally disturbed more than the unmarried ones for the reason that they fear for their beloved ones than their health. The result is similar to the findings by Ceri and Cicek (2021), that HCWs at the frontline who were away from their family for more than a week during the pandemic were highly affected by depression and anxiety.

\section{Conclusion}

From the above findings, it is clear that during the pandemic, HCWs were having the typical symptoms of anxiety such as nervousness, difficulty in concentrating, restlessness, and too much fear for everything. They also had the symptoms of Depression such as frustration and no interest in doing things, feeling no energy to carry out their routines, and worrying about everything. They underwent the PTSD symptom of getting disturbing thoughts and memories.

The results show that the HCWs were constantly living under stress, frustration, and pressure which was directly affecting their routines and practices. The troubles they were undergoing during the pandemic time were not visible as the mental disturbance was not visible to others. Their frustration and stress were left unnoticed and rather ignored by the authorities as they were supposed to keep treating the patients eventually.

\section{Recommendations}

HCWs are not ordinary citizens and they are the caretakers of the country so their health must be prioritized. The mental health of healthcare professionals is imminent and cannot be ignored. They must be considered as the country's national heroes. The concerned authorities should understand the mental issues of the HCWs and they should be given appropriate facilities, training, and moral support.

The following recommendations were suggested:

- To safeguard the mental health of the HCWs, their working hours and the number of patients should be reduced; logistic support should be provided and the support from the supervisors should be increased as suggested by Elbay et al. (2020).

- HCWs could be given more family time and easy rosters with flexible working hours.

- Lam et al. (2020) stated that the users of face masks reported less depression and hence sufficient PPEs should be provided so that HCWs can feel more secure and protected.

- Training for mental stress reliefs and more precautionary equipment should be provided to them to effectively fight against COVID-19.

- Psychological assistance services such as counseling could be introduced similar to the intervention services introduced by China during the COVID-19 outbreak (Chen et al., 2020; The State Council of China, 2020).

- $\quad$ Psychological hotline assistance and stress relief activities or Psychological Resilience Interventions as suggested by Albott et al. (2020) can be increased. 
- They should be motivated through lectures, pay raises, bonuses or rewards, expanded vacation time, and the full equipment for the safety from the COVID-19 virus.

Appropriate and immediate action should be taken to monitor and reduce anxiety and depression among those working in the frontline.

\section{References}

1. Al-Balushi, A. (2016 ). Evaluation of Occupational Stress Issues of the Nurses from Hospital in Sohar, Oman [Master Thesis Sohar University]. Oman.

2. Al-Balushi, S., \& Khan, F. R. (2017). Factors influencing the preference of private hospitals to public hospitals in Oman. International Journal of Management, Innovation \& Entrepreneurial Research EISSN, 3(2), 67-78. https://doi.org/10.18510/ijmier.2017.323

3. Albott, C. S., Wozniak, J. R., McGlinch, B. P., Wall, M. H., Gold, B. S., \& Vinogradov, S. (2020). Battle buddies: rapid deployment of a psychological resilience intervention for health care workers during the coronavirus disease 2019 pandemic. Anesthesia and analgesia, XXX(XXX), 1-12. https://doi.org/10.1213/ANE.0000000000004912

4. Alshekaili, M., Hassan, W., Al Said, N., Al Sulaimani, F., Jayapal, S. K., Al-Mawali, A., Chan, M. F., Mahadevan, S., \& Al-Adawi, S. (2020). Factors associated with mental health outcomes across healthcare settings in Oman during COVID-19: frontline versus non-frontline healthcare workers. BMJ Open, 10(10), e042030. https://doi.org/10.1136/bmjopen-2020-042030

5. Badahdah, A., Khamis, F., Al Mahyijari, N., Al Balushi, M., Al Hatmi, H., Al Salmi, I., Albulushi, Z., \& Al Noomani, J. (2020). The Mental Health of Health Care Workers in Oman During the COVID-19 Pandemic. International Journal of Social Psychiatry, 67(1), 90-95. https://doi.org/10.1177/0020764020939596

6. Bagozzi, R. P., \& Yi, Y. (1988). On the evaluation of structural equation models. Journal of the academy of marketing science, 16(1), 74-94. https://doi.org/https://doi.org/10.1007/BF02723327

7. Blekas, A., Voitsidis, P., Athanasiadou, M., Parlapani, E., Chatzigeorgiou, A. F., Skoupra, M., Syngelakis, M., Holeva, V., \& Diakogiannis, I. (2020). COVID-19: PTSD symptoms in Greek health care professionals. Psychological Trauma: Theory, Research, Practice, and Policy, 12(7), 812.

8. Borges, L. M., Barnes, S. M., Farnsworth, J. K., Bahraini, N. H., \& Brenner, L. A. (2020). A commentary on moral injury among health care providers during the COVID-19 pandemic. Psychological Trauma: Theory, Research, Practice, and Policy, 12(S1), S138-S140. https://doi.org/10.1037/tra0000698

9. Carmassi, C., Foghi, C., Dell'Oste, V., Cordone, A., Bertelloni, C. A., Bui, E., \& Dell'Osso, L. (2020). PTSD symptoms in healthcare workers facing the three coronavirus outbreaks: What can we expect after the COVID-19 pandemic. Psychiatry Research, 292, 113312. https://doi.org/10.1016/j.psychres.2020.113312

10. Ceri, V., \& Cicek, I. (2021). Psychological well-being, depression, and stress during COVID-19 pandemic in Turkey: A comparative study of healthcare professionals and non-healthcare professionals. Psychology, Health \& Medicine, 26(1), 85-97. https://doi.org/10.1080/13548506.2020.1859566

11. Chen, Q., Liang, M., Li, Y., Guo, J., Fei, D., Wang, L., He, L., Sheng, C., Cai, Y., \& Li, X. (2020). Mental health care for medical staff in China during the COVID-19 outbreak. The Lancet Psychiatry, 7(4), e15-e16. https://doi.org/10.1016/S2215-0366(20)30078-X

12. Choi, E. P. H., Hui, B. P. H., \& Wan, E. Y. F. (2020). Depression and Anxiety in Hong Kong During COVID-19. International Journal of Environmental Research and Public Health, 17(10), 3740. https://doi.org/10.3390/ijerph17103740

13. Cohen, P., West, S. G., \& Aiken, L. S. (2014). Applied multiple regression/correlation analysis for the behavioral sciences. Psychology Press.

14. Comrey, A. L., \& Lee, H. B. (2013). A first course in factor analysis. Psychology Press.

15. Conversano, C., Marchi, L., \& Miniati, M. (2020). Psychological distress among healthcare professionals involved in the covid-19 emergency: vulnerability and resilience factors. Clinical Neuropsychiatry, 17(2), 94-96.

16. Day, M. (2020). Covid-19: Four Fifths of Cases are Asymptomatic, China Figures Indicate. British Medical Journal, 369(m1375). https://doi.org/10.1136/bmj.m1375

17. De Kock, J. H., Latham, H. A., Leslie, S. J., Grindle, M., Munoz, S.-A., Ellis, L., Polson, R., \& O’Malley, C. M. (2021). A Rapid Review of the Impact of COVID-19 on the Mental Health of Healthcare Workers: Implications for Supporting Psychological Well-being. BMC Public Health, 21(1), 1-18. https://doi.org/10.1186/s12889-020-10070-3

18. Di Tella, M., Romeo, A., Benfante, A., \& Castelli, L. (2020). Mental Health of Healthcare Workers During the COVID-19 Pandemic in Italy. Journal of evaluation in clinical practice, 26(6), 1583-1587. https://doi.org/10.1111/jep.13444 
19. Elbay, R. Y., Kurtulmuş, A., Arpacioğlu, S., \& Karadere, E. (2020). Depression, anxiety, stress levels of physicians and associated factors in Covid-19 pandemics. Psychiatry Research, 290, 113130. https://doi.org/10.1016/j.psychres.2020.113130

20. Ettman, C. K., Abdalla, S. M., Cohen, G. H., Sampson, L., Vivier, P. M., \& Galea, S. (2020). Prevalence of depression symptoms in US adults before and during the COVID-19 pandemic. JAMA network open, 3(9), e2019686-e2019686. https://doi.org/10.1001/jamanetworkopen.2020.19686

21. Fornell, C., \& Larcker, D. F. (1981). Evaluating structural equation models with unobservable variables and measurement error. Journal of marketing research, 18(1), 39-50. https://doi.org/https://doi.org/10.1177/002224378101800104

22. Gefen, D., Straub, D., \& Boudreau, M.-C. (2000). Structural equation modeling and regression: Guidelines for research practice. Communications of the association for information systems, 4(1), 1-78. https://doi.org/https://doi.org/10.17705/1CAIS.00407

23. Greenberg, N., Docherty, M., Gnanapragasam, S., \& Wessely, S. (2020). Managing Mental Health Challenges Faced by Healthcare Workers during COVID-19 Pandemic. bmj, 368:m1211, 1-4. https://doi.org/10.1136/bmj.m1211

24. Hair, J. F., Black, W. C., Babin, B. J., Anderson, R. E., \& Tatham, R. L. (1998). Multivariate data analysis (Vol. 5, No. 3, pp. 207-219). In: Upper Saddle River, NJ: Prentice-Hall.

25. Hair, J. F., Sarstedt, M., Ringle, C. M., \& Mena, J. A. (2012). An assessment of the use of partial least squares structural equation modeling in marketing research. Journal of the academy of marketing science, 40(3), 414-433. https://doi.org/https://doi.org/10.1007/s11747-011-0261-6

26. Henderson, D., Sheetz, S. D., \& Trinkle, B. S. (2012). The determinants of inter-organizational and internal in-house adoption of XBRL: A structural equation model. International journal of accounting information systems, 13(2), 109-140. https://doi.org/https://doi.org/10.1016/j.accinf.2012.02.001

27. Huang, C.-C., Wang, Y.-M., Wu, T.-W., \& Wang, P.-A. (2013). An empirical analysis of the antecedents and performance consequences of using the Moodle platform. International Journal of Information and Education Technology, 3(2), 217. https://doi.org/http://doi.org/10.7763/IJIET.2013.V3.267

28. Hulland, J. (1999). Use of partial least squares (PLS) in strategic management research: A review of four recent studies. Strategic management journal, $20(2), \quad$ 195-204. https://doi.org/https://doi.org/10.1002/(SICI)1097-0266(199902)20:2<195::AID-SMJ13>3.0.CO;2-7

29. Hyland, P., Shevlin, M., McBride, O., Murphy, J., Karatzias, T., Bentall, R. P., Martinez, A., \& Vallières, F. (2020). Anxiety and depression in the Republic of Ireland during the COVID-19 pandemic. Acta Psychiatrica Scandinavica, 142(3), 249-256. https://doi.org/10.1111/acps.13219

30. Johnson, S. U., Ebrahimi, O. V., \& Hoffart, A. (2020). PTSD symptoms among health workers and public service providers during the COVID-19 outbreak. PloS one, 15(10), e0241032. https://doi.org/10.1371/journal.pone.0241032

31. Khanal, P., Devkota, N., Dahal, M., Paudel, K., \& Joshi, D. (2020). Mental health impacts among health workers during COVID-19 in a low resource setting: a cross-sectional survey from Nepal. Globalization and health, 16(1), 1-12. https://doi.org/10.1186/s12992-020-00621-Z

32. Lai, J., Ma, S., Wang, Y., Cai, Z., Hu, J., Wei, N., Wu, J., Du, H., Chen, T., \& Li, R. (2020). Factors Associated with Mental Health Outcomes Among Health care Workers Exposed to Coronavirus Disease 2019. JAMA network open, 3(3), e203976. https://doi.org/10.1001/jamanetworkopen.2020.3976

33. Lam, S. C., Arora, T., Grey, I., Suen, L. K. P., Huang, E. Y.-Z., Li, D., \& Lam, K. B. H. (2020). Perceived risk and protection from infection and depressive symptoms among healthcare workers in mainland China and Hong Kong during COVID-19. Frontiers in Psychiatry, 11, 686. https://doi.org/10.3389/fpsyt.2020.00686

34. Li, L., Cheng, S., \& Gu, J. (2003). SARS Infection Among Health Care Workers in Beijing, China. JAMA, 290(20), 2662-2663. https://doi.org/10.1001/jama.290.20.2662

35. Li, Z., Ge, J., Yang, M., Feng, J., Qiao, M., Jiang, R., Bi, J., Zhan, G., Xu, X., \& Wang, L. (2020). Vicarious traumatization in the general public, members, and non-members of medical teams aiding in COVID-19 control. Brain, behavior, and immunity, 88, 916-919. https://doi.org/10.1016/j.bbi.2020.03.007 36. Liu, C. H., Zhang, E., Wong, G. T. F., \& Hyun, S. (2020). Factors associated with depression, anxiety, and PTSD symptomatology during the COVID-19 pandemic: Clinical implications for US young adult mental health. Psychiatry Research, 290, 113172. https://doi.org/10.1016/j.psychres.2020.113172

37. Mann, F. D., Krueger, R. F., \& Vohs, K. D. (2020). Personal economic anxiety in response to COVID19. Personality and Individual Differences, 167, 110233.

38. Matheson, C., Robertson, H. D., Elliott, A. M., Iversen, L., \& Murchie, P. (2016). Resilience of primary healthcare professionals working in challenging environments: a focus group study. British Journal of General Practice, 66(648), e507-e515. https://doi.org/10.3399/bjgp16X685285 
39. Mazza, M. G., De Lorenzo, R., Conte, C., Poletti, S., Vai, B., Bollettini, I., Melloni, E. M. T., Furlan, R., Ciceri, F., \& Rovere-Querini, P. (2020). Anxiety and Depression in COVID-19 Survivors: Role of Inflammatory and Clinical Predictors. Brain, behavior, and immunity, 89, 594-600. https://doi.org/10.1016/j.bbi.2020.07.037

40. Naser, A. Y., Dahmash, E. Z., Al-Rousan, R., Alwafi, H., Alrawashdeh, H. M., Ghoul, I., Abidine, A., Bokhary, M. A., AL-Hadithi, H. T., \& Ali, D. (2020). Mental Health Status of the General Population, Healthcare Professionals, and University Students during 2019 Coronavirus Disease Outbreak in Jordan: A Cross-sectional Study. Brain and Behavior, 10(8), 1-13. https://doi.org/10.1002/brb3.1730

41. Naser, A. Y., Dahmash, E. Z., Alwafi, H., Alsairafi, Z. K., Al Rajeh, A. M., Alhartani, Y. J., Turkistani, F. M., \& Alyami, H. S. (2020). Knowledge and practices towards COVID-19 during its outbreak: a multinational cross-sectional study. MedRxiv, 1-17. https://doi.org/10.1101/2020.04.13.20063560

42. Ornell, F., Halpern, S. C., Kessler, F. H. P., \& Narvaez, J. C. d. M. (2020). The impact of the COVID19 pandemic on the mental health of healthcare professionals. Cadernos de saude publica, 36(4), e00063520. https://doi.org/10.1590/0102-311X00063520

43. Özdin, S., \& Bayrak Özdin, Ş. (2020). Levels and predictors of anxiety, depression and health anxiety during COVID-19 pandemic in Turkish society: The importance of gender. International Journal of Social Psychiatry, 66(5), 504-511. https://doi.org/10.1177/0020764020927051

44. Pappa, S., Ntella, V., Giannakas, T., Giannakoulis, V. G., Papoutsi, E., \& Katsaounou, P. (2020). Prevalence of depression, anxiety, and insomnia among healthcare workers during the COVID-19 pandemic: A systematic review and meta-analysis. Brain, behavior, and immunity, 88, 901-907. https://doi.org/10.1016/j.bbi.2020.05.026

45. Peteet, J. R. (2020). COVID-19 Anxiety. Journal of Religion and Health, 59, 2203-2204. https://doi.org/10.1007/s10943-020-01041-4

46. Rajkumar, R. P. (2020). COVID-19 and Mental Health: A Review of the Existing Literature. Asian journal of psychiatry, 52, 102066. https://doi.org/10.1016/j.ajp.2020.102066

47. Rossi, R., Socci, V., Pacitti, F., Mensi, S., Di Marco, A., Siracusano, A., \& Di Lorenzo, G. (2020). Mental health outcomes among healthcare workers and the general population during the COVID-19 in Italy. Frontiers in Psychology, 11, 1-9. https://doi.org/10.3389/fpsyg.2020.608986

48. Roy, A., Singh, A. K., Mishra, S., Chinnadurai, A., Mitra, A., \& Bakshi, O. (2021). Mental Health Implications of COVID-19 Pandemic and its Response in India. The International journal of social psychiatry, 67(5), 587-600. https://doi.org/10.1177/0020764020950769

49. Schafheutle, E. I., Seston, E. M., \& Hassell, K. (2011). Factors Influencing Pharmacist Performance: a Review of the Peer-Reviewed Literature. Health Policy, 102(2-3), 178-192. https://doi.org/10.1016/j.healthpol.2011.06.004

50. Serrano-Ripoll, M. J., Meneses-Echavez, J. F., Ricci-Cabello, I., Fraile-Navarro, D., Fiol-deRoque, M. A., Pastor-Moreno, G., Castro, A., Ruiz-Pérez, I., Campos, R. Z., \& Gonçalves-Bradley, D. C. (2020). Impact of viral epidemic outbreaks on mental health of healthcare workers: a rapid systematic review and metaanalysis. Journal of affective disorders, 277, 347-357. https://doi.org/10.1016/j.jad.2020.08.034

51. Sher, L. (2020). COVID-19, Anxiety, Sleep Disturbances and Suicide. Sleep Medicine, 70, 124-124. https://doi.org/10.1016/j.sleep.2020.04.019

52. Shreffler, J., Petrey, J., \& Huecker, M. (2020). The Impact of COVID-19 on Healthcare Worker Wellness: A Scoping Review. Western Journal of Emergency Medicine, 21(5), 1059. https://doi.org/10.5811/westjem.2020.7.48684

53. Tandon, R. (2020). The COVID-19 pandemic, personal reflections on editorial responsibility. Asian journal of psychiatry, 50, 102100. https://doi.org/10.1016/j.ajp.2020.102100

54. Tang, W., Hu, T., Hu, B., Jin, C., Wang, G., Xie, C., Chen, S., \& Xu, J. (2020). Prevalence and correlates of PTSD and depressive symptoms one month after the outbreak of the COVID-19 epidemic in a sample of home-quarantined Chinese university students. Journal of affective disorders, 274, 1-7. https://doi.org/10.1016/j.jad.2020.05.009

55. Tenenhaus, M., Vinzi, V. E., Chatelin, Y.-M., \& Lauro, C. (2005). PLS path modeling. Computational statistics \& data analysis, 48(1), 159-205. https://doi.org/10.1016/j.csda.2004.03.005

56. The State Council of China. (2020). Notice on the Establishment of a Psychological Assistance Hotline in Response to the Epidemic Pneumonia Mechanism - Fa (2020) No. 18. State Council News. Retrieved 3rd Mar. 2020, from http://www.gov.cn/xinwen/2020-02/02/content_5473937.htm

57. UNESCO-UNEVOC International Centre. (2012). Entrepreneurship Education, Oman. https://unevoc.unesco.org/fileadmin/user_upload/pubs/Entrepreneurship\%20education\%20-\%200man.pdf 58. Ustun, G. (2021). Determining depression and related factors in a society affected by COVID-19 pandemic. The International journal of social psychiatry, 67(1), 54-63. https://doi.org/10.1177/0020764020938807 
59. Vodă, A. I., \& Florea, N. (2019). Impact of personality traits and entrepreneurship education on entrepreneurial intentions of business and engineering students. Sustainability, 11(4), 1192. https://doi.org/10.3390/su11041192

60. Wallace, J. E., Lemaire, J. B., \& Ghali, W. A. (2009). Physician Wellness: a Missing Quality Indicator. The Lancet, 374(9702), 1714-1721. https://doi.org/10.1016/S0140-6736(09)61424-0

61. Wilson, W., Raj, J. P., Rao, S., Ghiya, M., Nedungalaparambil, N. M., Mundra, H., \& Mathew, R. (2020). Prevalence and predictors of stress, anxiety, and depression among healthcare workers managing COVID19 pandemic in India: a nationwide observational study. Indian Journal of Psychological Medicine, 42(4), 353-358. https://doi.org/10.1177/0253717620933992 